This is an electronic reprint of the original article. This reprint may differ from the original in pagination and typographic detail.

Author(s): Ratzinger, Nicole V.S.; Audousset-Coulier, Sophie; Kettunen, Jaana; Lesage, Cedric

Title: Joint Audit: Issues and Challenges for Researchers and Policy-Makers

Year: $\quad 2013$

Version:

Please cite the original version:

Ratzinger, N. V., Audousset-Coulier, S., Kettunen, J., \& Lesage, C. (2013). Joint Audit: Issues and Challenges for Researchers and Policy-Makers. Accounting in Europe, 10(2), 175-199. https://doi.org/10.1080/17449480.2013.834725

All material supplied via JYX is protected by copyright and other intellectual property rights, and duplication or sale of all or part of any of the repository collections is not permitted, except that material may be duplicated by you for your research use or educational purposes in electronic or print form. You must obtain permission for any other use. Electronic or print copies may not be offered, whether for sale or otherwise to anyone who is not an authorised user. 


\title{
Joint audit: Issues and challenges for researchers and policy-makers
}

\author{
Nicole Ratzinger-Sakel* \\ Ulm University \\ Ulm, Germany \\ Sophie Audousset-Coulier \\ Concordia University \\ Montreal, Canada \\ Jaana Kettunen \\ University of Jyväskylä \\ Jyväskylä, Finland \\ Cédric Lesage \\ HEC Paris \\ Jouy-en-Josas, France
}

* Corresponding author

The authors acknowledge the financial support of the Institute of Chartered Accountants of Scotland (ICAS). Cédric Lesage acknowledges the financial support of the HEC Foundation (Project F1103). He is member of the GREGHEC, CNRS Unit, UMR 2959. This paper is based on a literature review conducted for ICAS, which is available here http://icas.org.uk/jointaudit/. 


\title{
Joint audit: Issues and challenges for researchers and policy-makers
}

\begin{abstract}
The publication of the European Commission Green Paper, “Audit Policy: Lessons from the Crisis" in October 2010, has stirred up a lively debate on the role of joint audits. This literature review identifies and evaluates, for the benefit of future research and regulators, existing evidence about joint audits. We find limited empirical support to suggest that joint audits lead to increased audit quality, but some empirical support to suggest that joint audits lead to additional costs. Overall, this paper indicates that joint audit should be seen as a mechanism that is embedded in a broader institutional context, and not be considered in isolation from other factors that might impact the audit market. The results indicate that various country-level characteristics are simultaneously at play. While joint audits can potentially enhance the audit market competition by allowing smaller audit firms to maintain larger market shares, the related impact on audit quality has not yet been clearly demonstrated and thus provides a promising avenue for future research.
\end{abstract}




\section{Introduction}

The global financial crisis prompted questions about the scope and quality of the external audit. A major concern was the risk created by the high audit market concentration following the Enron scandal and the associated collapse of Arthur Andersen. As expressed by the British House of Lords, "All witnesses fear the real possibility that one of the Big 4 might withdraw leaving a Big $3[\ldots]$. Loss of one of the Big 4 would restrict competition and choice to an unacceptable extent" (HoL, 2011, § 27). In an effort to remedy this situation, the European Community (EC) published the Green Paper ‘Audit Policy: Lessons from the Crisis’ (EC, 2010) proposing possible solutions, of which the joint audit was one of the most debated. The Green Paper was also motivated by concerns that the Big 4 dominate the European listed market, with the noticeable exception of France, where mandatory joint audit has been implemented since 1966 (Huber, 2011).

Following the Green Paper, in November 2011 the European Commission issued a proposal that encouraged the practice of joint audit on a voluntary basis. It recommended that mandatory audit firm rotation be extended from six years to nine years if joint audits are performed (EC, 2011a, art. 31, para. 1, sentence 4). However, this suggestion has not been supported by the Committee on Legal Affairs (JURI) of the European Parliament, which instead suggested an extended rotation period of 25 years (European Parliament, 2012, p. 85). It currently remains to be seen whether the EC will make joint audits mandatory, encourage them or simply cease to consider them any longer, be it on a mandatory or voluntary basis.

The objective of this literature review is to identify and evaluate existing evidence on the use of joint audit, in particular its impact on audit quality, audit costs and audit market concentration. It contributes to the joint audit literature in two ways: First, it provides a comprehensive overview of the current academic knowledge about joint audit by presenting and discussing the evidence and the main limitations. Second, it emphasises the lack of prior 
evidence in various areas and proposes important avenues for future research so as to allow for a more thorough understanding of joint audit and its impacts.

The literature review is structured as follows: Section 2 defines joint audit and explains the method used to conceptualise the literature review. Section 3 describes the joint audit regulatory environments and also reviews practical challenges. Section 4 provides evidence of the impact of joint audit on audit quality, audit costs and audit market concentration. Section 5 presents the results of prior research about other characteristics of joint audits, including the determinants and consequences of auditor pair choices. Section 6 critically discusses the limitations of prior studies. Finally, Section 7 provides avenues for future research, followed by concluding remarks in Section 8 .

\section{Terminology and methodology}

\subsection{Definition of joint audit}

Joint audit can be defined as an audit in which financial statements are audited by two or more independent auditors in a way that involves: coordination of the audit planning; shared audit effort; cross reviews and mutual quality controls; and issuance of one single auditor's report signed by the auditors who are jointly liable.

A joint audit needs to be distinguished from a 'double audit' (i.e., audit work is fully performed twice) or a 'dual audit' (i.e., each auditor audits distinct sets of financial information and issues two distinct audit opinions). It also differs from audits with two partners of the same audit firm signing the audit report (Karjalainen, 2011).

\subsection{Method}

This literature review includes both published work and grey literature such as working papers and $\mathrm{Ph} . \mathrm{D}$. monographs in order to provide a complete picture of the existing research, including 
empirical studies, conducted in mandatory and voluntary joint audit settings, and analytical modelling, non-empirical studies.

This paper focuses primarily on the effect of joint audit on audit quality and audit costs, as these criteria have also dominated the joint audit debate and the responses to the Green Paper (EC, 2011b). It also elaborates on the impact of joint audit on market concentration, and on the impact of audit firm pair choice on audit costs and audit quality in joint audit settings.

\section{Context and setting of joint audits}

The majority of the extant literature examines joint audit in Denmark and France. This section presents the joint audit requirements in these two countries. In addition, it provides a short overview of joint audit requirements for other countries. Finally, some of the practical challenges that may be faced by the various stakeholders in joint audit contexts are also presented and discussed.

\subsection{Joint audits in Denmark and France}

\subsubsection{Denmark}

In Denmark, listed and state-owned companies were required to be audited by two mutually independent auditors from 1930 to 2004. Danish law did not specify how the audit work or audit fees were to be shared between the two auditors, often resulting in cases in which one audit firm would bill more than 80 per cent of the audit fees (Thinggaard and Kiertzner, 2008). The abandonment of mandatory joint audit was motivated by unnecessarily high audit costs (Danish Financial Statement Act, 2001, The Proposal to the Act, §135) and an assumption that a single auditor can provide a more holistic approach (Holm and Warming-Rasmussen, 2008). 


\subsubsection{France}

Audit regulation in France has its roots in a long tradition of the voluntary use of multiple controllers for large companies (Bennecib, 2004; Audousset-Coulier, 2008) and joint audit has been mandated since 1966 (Loi du 24 juillet 1966, Art. 223-3). The 1966 Act initially focused on listed firms and on non-listed firms with a share capital value exceeding a certain threshold (Audousset-Coulier, 2008). However, since 1984, joint audit has been mandatory for all companies preparing consolidated financial statements (Code de commerce, Art. L 823-2). In the 1970s, the accounting profession and financial market authorities increasingly criticised the joint audit for its inability to ensure collegiality, a drawback attributed to difficulties with allocating the audit tasks, agreeing on common audit programmes and applying consistent methodologies (Marmousez, 2008). Professional practice standards (NEP-100, 2011) now require a balanced audit work allocation between both auditors 'to ensure an efficient dual control mechanism' (Gonthier-Besacier and Schatt, 2007, p. 141).

\subsection{Other examples of joint audit requirements}

South Africa had a mandatory joint audit requirement for the banking industry during the 1990 to 2003 period (Banks Amendment Act, 2003), while Sweden mandated joint audits for the banking industry until 2004 (Lag om bank- och finansieringsrörelse, 2004) and for the insurance industry until 2010 (Försäkringsrörelselag, 2010). Nowadays, the Swedish Financial Supervision Authority (SFSA, Finansinspektionen in Swedish), can appoint an auditor to jointly act with the other auditor of the bank (Lag om bank- och finansieringsrörelse, 2004; Försäkringsrörelselag, 2010, sec. 14) or the insurance (Försäkringsrörelselag, 2010) company respectively. A mandatory joint audit requirement for the banking sector, combined with a twoyear rotation period (Richardson, 2001), was also in place in Canada during the 1923-1991 period (1923 revision of the Bank Act). Furthermore, some developing countries such as Algeria, Congo, India, the Ivory Coast and Kuwait have introduced mandatory joint audits for 
specific types of companies, e.g., banks, listed and state-owned companies. To date, empirical evidence on these countries is either extremely limited or non-existing. Furthermore, although numerous jurisdictions allow joint audits on a voluntary basis (EC, 2001, p. 34), only those countries where a significant number of companies have opted for joint audits can provide generalizable findings.

\subsection{Practical challenges of undertaking joint audit}

The execution of joint audit has many practical challenges, such as the allocation of audit tasks, the coordination process and the resolution of differences in audit opinion.

\subsubsection{The balanced joint audit challenge}

Do joint audit regulations always lead to 'real' joint audits? In the initial years of application in France, situations where the two joint auditors were not independent from each other were not uncommon. The Le Portz report in 1993 pointed to situations (representing 20 per cent of the 100 largest French firms) where the two joint auditors were affiliated with the same audit network. In the 1993 revised code of professional conduct, this practice was then banned, resulting in a redistribution of audit appointments in favour of smaller audit firms. For the 19961998 period, Piot (2003) shows that auditor switch decisions were essentially a way to discontinue the 'fictitious' joint audit situations.

Furthermore, a balanced share of the audit effort seems desirable in a joint audit setting, because unbalanced situations with a 'dominant' auditor are perceived as non-effective joint audits (Bennecib, 2004; Le Maux, 2004; Thinggaard and Kiertzner, 2008). However, even though the French auditors' code of professional conduct requires that the audit work be shared in a balanced way (qualitatively and quantitatively), a recent report of the French Autorité des Marchés Financiers (The Autorité des Marchés Financiers (AMF) is an independent public body with legal personality and financial autonomy) showed cases with significantly imbalanced fee distribution between the two joint auditors (AMF, 2011). 
To decrease audit market concentration, the Green Paper proposes joint audits and promotes the idea of appointing at least one non-systemic (non-Big 4) audit firm paired with a larger audit firm. ${ }^{1}$ This constrained choice could, however, lead to non-optimal situations: a smaller audit firm will not always have the necessary resources to conduct a significant part of the audit work in large, diversified and geographically dispersed companies, thus resulting in non-balanced shares of the work between joint auditors. Therefore, such a context could potentially reduce the likelihood of achieving the expected enhancement of audit quality, although it would meet the objective of enhancing market competition.

\subsubsection{Audit term duration and audit rotation issues}

The continuity of the audit knowledge can be preserved in a joint audit setting if the joint auditors rotate during different years. In a voluntary setting such as provided by the current South African regulation (Companies Act, 2008), if a company appoints two or more auditors, it must ensure auditor rotation once every five years and ensure that not all joint auditors relinquish office in the same year. This legislation thus emphasises continuity by prohibiting the simultaneous switching of both auditors. In France, the joint audit regulation is coupled with a fixed minimum auditor appointment duration of six years. In practice, both simultaneous and non-simultaneous rotation of the joint auditors occur in France (Audousset-Coulier, 2012). In the same vein, the EC regulatory proposal recommended a minimum duration of two years for the audit appointment and the rotation of auditors after six years, with the possibility to keep auditors for a longer period of nine years when 'more than one auditor' is used. However, the interrelation between a joint audit system, fixed-term engagement duration for a period longer than one year, and auditor rotation requirements after a certain maximum tenure remains an important yet unresolved issue. Further research is thus required to assess the respective merits

\footnotetext{
${ }^{1}$ The regulatory proposal of November 2011 does not require a pairing of a Big 4 audit firm with a non-Big 4 audit firm (EC, 2011a, art. 31, para. 1, sentence 4).
} 
of competing scenarios (joint versus single audit, short versus long appointment terms, coinciding versus distinct renewal dates and various rotation requirements).

\subsubsection{The effect on the audit market dynamics}

One potential adverse effect of joint audit is that the audit market becomes 'sticky' and that the number of audit firms to choose from becomes reduced. In practice, large companies have been known to systematically avoid choosing the same audit firm(s) than their main competitors. Furthermore, if local regulation prevents companies from hiring their incumbent auditors for non-audit services, then a company may well choose to have only one Big 4 paired with one non-Big 4 auditor in order to be able to hire the other Big 4 firm for non-audit services. For these reasons, the joint audit system creates potentially even more severe and unexpected restrictions on auditor choice, particularly in industries where the number of industry-specialist auditors is small (Piot, 2008). This issue begs the question: are the constraints created by the joint audit system desirable in terms of auditor choice? As yet unanswered, this question calls for future research on the audit market dynamics in France, including perceptions of audit clients, of financial statement users and of various other stakeholders.

\subsubsection{Stakeholders' perspectives on joint audit}

The views held by companies, auditors and other stakeholders on joint audit may differ. Some companies may prefer joint audit in order to signal a higher level of audit quality to the market. Big 4 and second-tier audit firms may also have divergent views, as shown by an analysis of the responses to the Green Paper by Lesage et al. (2012): Big 4 audit firms argue that joint audit increases costs; and second-tier audit firms mainly stress the potential enhancement in audit quality. Each group of auditors thus appears to seek to protect their private interests (Lesage et al., 2012). Other stakeholders have somewhat mixed positions on joint audit. In their responses to the Green Paper, many investors and associations representing companies and financial statement preparers state that they fear the related increase in the costs of audits, the lack of 
clear lines of responsibility between the joint auditors, and a general lack of benefits (EC, 2011b).

\section{Impact of joint audits}

This section focuses on the impact of joint audits on audit quality, audit costs and market concentration. Studies on both voluntary and mandatory joint audit settings are discussed below and summarised in Table 1.

[Insert Table 1 here]

\subsection{Audit quality}

In the Danish setting, Holm and Thinggaard (2011) and Lesage et al. (2012) document that joint audits do not have an impact on audit quality as proxied by abnormal accruals measures. The lack of a positive impact of joint audit on audit quality is also supported by Lesage and Ratzinger-Sakel (2012) in a matched-pair study of France and Germany. Contrary to these findings, Zerni et al. (2012) document in the voluntary Swedish joint audit setting that companies opting voluntarily for joint audits have a higher degree of earnings conservatism and lower abnormal accruals (both are proxies for audit quality). They also have better credit ratings and lower risk forecasts for insolvency (both being proxies for perceived audit quality) than companies with only one auditor. Zerni et al. (2010) find in the Swedish setting that, compared to single audit cases, firms with joint auditors (regardless of the type of auditor selected) have the highest perceived audit quality, because the market values joint auditors as a monitoring mechanism that helps prevent the expropriation of minority shareholders.. While the studies thus far have either documented no impact or a positive impact of joint audit on (perceived) audit quality, the analytic modelling conducted by Deng et al. (2012) suggests that joint audits may compromise auditor independence as they give clients the opportunity for 'opinion shopping'. Moreover, the competition between the two auditors creates incentives to 'please' 
the client. Another impairment of audit quality in the joint audit setting, especially in cases when a technologically less efficient audit firm (a small audit firm) is chosen, is the free-rider problem, i.e., one auditor relies on the other auditor's work, resulting in a lower reliability of the audit evidence.

\subsection{Audit costs}

The joint audit in Denmark appears to be associated with higher audit costs, measured by audit fees (Holm and Thinggaard, 2011; Lesage et al., 2012). The fee discount for single audits can only be documented in the first year after the switch from a joint to a single audit. This discount is mainly driven by now single-audited companies that were previously audited by two audit firms, both of which had a significant stake in the joint audit (Holm and Thinggaard, 2011). Furthermore, a shift between the disclosed fee categories, i.e., between audit and non-audit fees, appears likely, as no impact on total fees was found (Lesage et al., 2012). Consistent with the finding of higher audit costs caused by the joint audit in the Danish setting, André et al. (2012) document a fee premium in France compared to Italy and the United Kingdom. The authors attribute this finding to higher coordination costs in joint audit settings. The Lesage and Ratzinger-Sakel (2012) matched-pair study on France and Germany confirms a fee premium (for both audit and total fees) in France. However, Lesage and Ratzinger-Sakel (2012) stress that they cannot rule out that the higher fees might also be caused by other country-specific differences, e.g., the fixed six-year term of French auditors.

Using data from Denmark, Finland and Sweden, Ittonen and Peni (2012) document that voluntary joint audit is associated with lower audit fees. In contrast, Zerni et al. (2012) find that opting for joint audit leads to higher audit fees in Sweden. These conflicting results may have been influenced by certain characteristics of the client companies that have voluntarily chosen a joint audit or by the fact that the joint auditor pair is not selected 'at random'. Indeed, the joint audit 'premium', if any, might be driven by the potential existence of a Big 4 premium in a joint 
audit setting if one (or two) Big 4 auditor(s) is chosen. ${ }^{2}$ The analytical modelling by Deng et al. (2012) also suggest that joint audits lead to lower audit fees, especially in cases in which the technological difference between the two audit firms is small and/or when the big audit firm bears a large proportion of the audit costs.

\subsection{Audit market concentration}

The concentration of the audit market in the hands of very few large suppliers is a concern that has focused the attention of both regulators and researchers (e.g. Simunic, 1980; Wolk et al., 2001, in the U.S.; Beattie et al., 2003, in the U.K.). An increased market concentration and therefore a perceived lower level of market competition restrains the number of suppliers to choose from and creates the possibility of abnormally high prices due to monopoly rents as well as suboptimal audit quality due to an absence of effort and investments. In the Green Paper, the EC indicates that the current level of audit market concentration creates a systemic risk because the collapse of another big international audit network would significantly disrupt the audit market dynamics and suggests that joint audits could be used to reduce the concentration of the audit market (Quick, 2012).

Empirical results by Ballas and Fafaliou (2008) and Piot (2007) confirm the lower audit market concentration in France as compared to other European countries, which is often cited as a direct and desirable consequence of the joint audit regulation. Ballas and Fafaliou (2008) also find that France and Denmark are the only two countries where audit market concentration significantly decreased after the demise of Arthur Andersen. Although the French joint audit system seems to allow medium and small audit firms to maintain relatively large market shares in terms of number of clients, Big 4 audit firms nevertheless earn a large proportion of audit fees (Broye, 2007). Big 4 audit firms dominate the audit market of large listed companies in France, but the audit market concentration decreases significantly for medium and small-sized

\footnotetext{
${ }^{2}$ The effect of joint auditor pair choices on audit fees are presented in Section 5.
} 
listed companies (Broye, 2007). Furthermore, audit market concentration is higher in certain regulated industries, such as construction and financial institutions (Piot, 2008).

\section{Other studies on joint audit}

Aside from studies that examine the impact of joint audit on audit quality, audit costs and audit market concentration, other types of studies have been conducted in joint audit contexts. Most of these do not aim to compare joint audits to single audits, and therefore do not provide direct evidence about the benefits or drawbacks of joint versus single audits; however, they do provide interesting evidence about the specifics of joint audit. This evidence can be grouped into the following four categories: determinants of the choice to opt for joint audits in voluntary settings; determinants of the joint auditor pair choice; consequences of the joint auditor pair choice on audit fees; and, consequences of the joint auditor pair choice on audit quality. The results of the corresponding empirical studies are discussed below and summarised in Table 2.

[Insert Table 2 here]

\subsection{Determinants of the choice to opt for joint audits in voluntary settings}

In the Swedish voluntary joint audit context, both board members' equity ownership and the presence of a strong minority ownership increase the likelihood that a firm employs joint auditors (Zerni et al., 2010). However, Swedish law provides minority shareholders with the right to appoint a second auditor. Pursuant to the Swedish Companies Act (Aktiebolagslag, 2005), minority shareholders are entitled to recommend that a second auditor, a co-auditor, be appointed by the Länsstyrelsen (Länsstyrelsen is the county administrative board) if at least 10 per cent of the shareholders or $1 / 3$ of the shares represented at a general meeting support this appointment.

\subsection{Determinants of joint auditor pair choice}


The determinants of auditor pair choice in the French joint audit context have been examined by Francis et al. (2009). Consistent with agency theory, they find that companies with less concentrated ownership structures and lower rates of family ownership are more likely to appoint at least one Big 4 audit firm. While Francis et al. (2009) put the emphasis on characteristics of the ownership structure, Marmousez (2012) analyses how client size and corporate governance mechanisms influence the decision to choose zero Big 4, one Big 4 paired with a non-Big 4, or two Big 4 auditors. She finds that smaller client companies have no incentive to hire two Big 4 auditors, while larger client companies select at least one Big 4 auditor. For medium-sized companies, the existence of an audit committee is positively associated with the choice of two Big 4 auditors. During transition from a mandatory to a voluntary joint audit system in Denmark, joint auditor pair choices seem to have been used as an agency mechanism to mitigate threats to auditor independence as non-audit service fees are lower when joint audits are undertaken (Holm and Thinggaard, 2012).

\subsection{Consequences of the joint auditor pair choice and of the distribution of audit fees between}

\section{joint auditors}

Audousset-Coulier's (2012) work demonstrates that choosing two Big 4 auditors does not lead to the payment of a 'double' Big 4 premium in France. Moreover, when two Big 4 auditors are selected by a client company, the Big 4 premium is shared between the two Big 4 auditors. This finding suggests that the choice of two Big 4 audit firms is a 'sound economic choice' for the largest, globalised companies, as this corresponds to their specific needs (Audousset-Coulier, 2012, p. 7). In the Kuwait context, however, Shammari et al. (2008) find that the audit firm pair choices have no impact on audit fees, and that neither companies audited by two Big 4 audit firms nor those audited by one Big 4 and one local audit firm pay a fee premium.

In the Danish setting, a negative association between the 'de facto' joint audit (a balanced audit fee allocation between both auditors) and audit fees can be documented for the large-client 
segment of the audit market (Thinggaard and Kiertzner, 2008). In contrast to the findings from Denmark (Thinggaard and Kiertzner, 2008), Gonthier-Besacier and Schatt (2007) show that balanced allocation between the auditors does not affect audit fees in France. They also show that companies audited by two Big 4 audit firms have a lower audit fee-size ratio compared to companies audited by other types of auditor pairs. The authors attribute this finding to a more balanced share of expertise and risks between the two Big 4 audit firms.

\subsection{Consequences of joint auditor pair choice on audit quality}

Since the seminal work of DeAngelo (1981) and Palmrose (1986), the empirical audit literature has developed a prolific stream of research that discusses and demonstrates that Big 4 audit firms have incentives to provide higher quality audits and that they charge a Big 4 fee premium. In the French joint audit setting, the choice of two Big 4 auditors is associated with smaller abnormal income-increasing accruals (Francis et al., 2009) and with a decrease in the number of related party transactions (Bennouri et al., 2012). Regarding the former finding, it appears that companies with higher agency costs are more likely to be audited by higher-quality audit pairs (Francis et al., 2009). While two Big 4 auditors appear to constrain earnings management and limit the number of actual related party transactions, they fail to improve impairmenttesting disclosure (Lobo et al., 2013). Based on game theory and referring to the 'prisoner's dilemma' argument, the analytic model by Lobo et al. (2013) suggests that neither of the Big 4 auditors have an incentive to take corrective action and to push for more impairment-testing disclosures, as both Big 4 auditors share the reputational cost.

\section{Discussion}

In this section, we address certain limitations of prior research: scarcity of published research, use of proxies, cross-country comparisons and selection bias.

\subsection{Scarcity of prior research}


The first critical issue, from a general perspective, is the scarcity of joint audit literature as a whole. One reason for the lack of sufficient prior evidence might be the small number of mandatory joint regimes. In Europe, only France mandates the joint audit, while Denmark has abolished it after 75 years in 2005. Furthermore, the non-European countries that require joint audits are either emerging markets (e.g., India) or countries with unstable political conditions (e.g., Congo). Hence, significant data access restrictions exist. In addition, an empirical investigation of the French experience is problematic, because there is no case of single audit in France that could be used as a comparable benchmark, as every company that prepares consolidated financial statements is required to appoint at least two independent auditors. As a consequence, from a methodological perspective, no reference group exists in France. Hence, an examination of the benefits and the drawbacks of the joint audit versus the single audit can only be conducted in cross-country studies that use both French data and other country data. Empirical research on voluntary joint audit regimes assumes that the number of voluntary joint audits is high enough to provide sufficient data to work with. However, as illustrated by Germany or Greece, the number of joint audits is often very limited in these countries. For example, in 2005 only four listed non-financial companies used a voluntary joint audit in Germany, and only five in Greece (Maggina, 2012).

\subsection{The use of proxies to operationalise audit quality and audit costs}

As audit quality is not directly observable, the audit literature developed proxies to model and measure audit quality. These proxies are subject to limitations and are criticised by practitioners. Academics acknowledge the difficulty of capturing and measuring the complex concept of audit quality. For instance, Carcello et al. (1992) surveyed the differences in the perception of audit quality attributes across the various stakeholders involved in the preparation and the use of financial statements. Unfortunately, these attributes are not measurable based on disclosed financial statement information. Given that only audit outcomes are observable by 
financial statement users, Francis (2004) identifies two proxies for audit quality that directly refer to observable audit outcomes: audited financial statements and auditors' reports. Besides these there are also other, rather indirect proxies for audit quality that capture certain attributes of the audit firm (e.g., auditor size and reputation) or of the audit process and auditor-client relationships (e.g., auditor industry specialization, audit effort, auditor independence).

In this section, we discuss only the two audit quality proxies that refer to audit outcomes. Regarding the quality of the audited financial statements, it is assumed that high quality earnings derive from high quality audits. This relation is based on the rationale that managers use the discretion provided in financial reporting standards to intentionally manipulate earnings and that it is the role of the auditor to constrain excessive earnings management. Therefore, to link earnings quality attributes to audit characteristics, researchers test whether there are 'systematic differences in audit outcomes, i.e., earnings quality, conditional on certain audit characteristics' (Francis, 2011). However, earnings quality itself needs to be modelled. While there are several measures for financial reporting quality, the extent of earnings management is commonly captured by abnormal accruals (e.g., Becker et al., 1998; Francis et al., 2005). These models (e.g., Jones, 1991; DeFond and Park, 2001) follow the rationale that accounting accruals are composed of a 'normal' part, which is not subject to manipulation, and an 'abnormal' part, which is subject to manipulation. One drawback of these models is their limited predictive accuracy and power to detect earnings management. However, they continue to be used to identify differences in audit quality (Francis and Wang, 2008; Francis et al., 2009).

Compared to discretionary accruals, using the auditor's report to proxy for audit quality has the advantage that the auditor's report directly reflects the auditor's decision (DeFond et al., 2002; DeFond and Francis, 2005; Robinson, 2008). Client's management tends to have a negative view of a going concern modified audit opinion (Kida, 1980; Mutchler, 1984). Hence, if auditor independence is compromised, the auditor will be more likely to concede to the wishes of client 
management and to abstain from reporting going concern problems in the auditor's report (Craswell, 1999). However, none of the joint audit studies used this proxy for audit quality, mainly because they are conducted in relatively small markets where modified audit opinions are rare and hence where the variance of this variable would be too low.

While the discussion above relates to proxies for audit quality, one other important aspect in the joint audit debate, namely audit costs, is also difficult to measure. Insights into the auditor's cost structure are not publicly available. As a consequence audit fees have to be used, acknowledging that they are neither a direct measure of audit costs nor of audit effort. For example, in some engagements auditors do not charge their clients for additional work, and in that case audit fees fail to accurately reflect the audit effort and cost (Schelleman and Knechel, 2010). As audit fees are the only publicly available data in this regards, they tend to be used by researchers as a proxy for audit cost. In studies examining the real cost of audits, access to proprietary data provided by audit firms, such as audit files and logs of audit hours spent on client files, can provide invaluable material to researchers (Niemi, 2002).

\subsection{Cross-country studies}

The general problem inherent in cross-country studies is that all potential differences between countries are identified by means of the 'country dummy variable', which captures not only the impact of the joint audit but also other institutional differences. In studies comparing France to other countries, for example, this variable would identify the ban of joint provision of audit and non-audit services and the six-year fixed term for French auditors.

\subsection{Self-selection bias}

As shown in previous research, joint auditors are not selected at random. Therefore, the selection of joint auditor pairs by client companies necessitates the use of sophisticated statistical models in research in order to take into account the propensity of companies to select zero, one or two Big 4 audit firms as joint auditors according to their specific needs. In order to 
control for the propensity to choose diverse configurations of auditor pairs, and in an attempt to rule out this selection bias, several researchers have developed and applied two-stage models (Heckman, 1979) that are adapted to the specific joint auditor selection (Audousset-Coulier, 2012; Bennouri, 2012). In addition, high-quality auditors may well select low-risk clients in order to mitigate the overall risk within their client portfolio, which, in turn, introduces a risk of reverse causality that can influence the results in empirical models.

\section{Opportunities for future research}

The limitations and practical challenges of joint audit indicated throughout this paper yield opportunities for future research, in particular qualitative research.

\subsection{Audit quality}

Future research on the quality aspect of joint audits could examine, in a voluntary joint audit regime, the motivations behind the decision to employ two independent auditors instead of one and the basis for the selection of joint auditor pairs. Auditors in both voluntary and mandatory joint audit regimes could also be surveyed or interviewed to obtain information about risk assessment, audit planning and work distribution in joint audits. These insights could then provide some indication of whether an increase in audit quality can be expected in joint audit contexts. Regarding the quality of the audit process, first, future research using lab-experiment designs could investigate the potential existence of free-rider concerns in joint audit contexts. An experiment that examines whether one of the audit firms involved in a joint audit indeed relies on the other audit firm's work would provide additional insights about audit quality in joint audit settings. If a free-rider problem can be observed, the potential positive impact of joint audits on audit quality - simply caused by the fact that two independent auditors conduct the audit - would be negatively impacted. Second, the communication and information exchange between the two competing audit firms could be studied to examine whether joint 
audit actually results in suboptimal collaboration. Third, qualitative research could focus on how significant differences in audit opinions are resolved. Finally, qualitative research about joint audit would benefit greatly from an access to proprietary data from audit firms, as this would allow researchers to conduct case studies and to analyse in detail how the audit effort is shared, how competencies are combined and how professional judgement is exercised in a joint audit setting.

Another fruitful avenue for future research would be to study how the joint audit system influences the structure and effectiveness of the quality controls and reviews enforced by the accounting profession and the oversight boards. One of the advantages of joint audit is that it constitutes a systematic peer-review system. Qualitative research would be useful to examine the extent to which the joint audit system successfully enhances fraud detection. In France, the Vivendi Universal scandal in the early 2000s revealed that the joint liability of joint auditors creates a strong incentive to reveal fraudulent behaviour and accounting irregularities. Whereas Arthur Andersen remained silent about the accounting treatment of the BSkyB acquisition, the non-Big auditor Salustro Reydel disclosed the accounting irregularity with the support of the financial market authorities (Bédard et al., 2012, p. 7).

Lastly, large-scale surveys could be beneficial in order to identify the perceptions of different types of stakeholders, and lab-experiment studies could be conducted to provide additional insight into the perception of audit quality when single audits or joint audits are used, depending on the types of auditors chosen.

\subsection{Audit cost}

Future research on the cost aspect of joint audits could survey audit firms in a voluntary joint audit regime to inquire about the additional effort associated with joint audits and about coordination costs and perceived risks. Such surveys could also serve to assess whether higher 
costs, if any, are passed on to the client, resulting in higher audit fees. Analytical modelling could also provide further insights.

\subsection{Audit market concentration}

The lively debate on joint audit in Europe was primarily driven by the EC's concern about the high level of concentration in the audit market and its related systemic risk. However, although there are quite a few studies on the consequences of audit market concentration on the quality of audited financial statements (e.g., Boone et al., 2012; Francis et al., 2012), and several studies providing descriptive insights about the French audit market (Broye, 2007; Piot, 2007; Piot, 2008), none empirically examined the link between joint audit, audit market concentration and the consequences of market concentration in terms of audit cost and audit quality.

\section{Conclusion}

The aim of this literature review was to identify and evaluate existing evidence on the use of joint audit. The main conclusions are as follows. First, there is limited empirical support that joint audit leads to increased audit quality. The scarce evidence available is contradictory. On the one hand, no link has been established between audit quality and joint audit in a mandatory joint audit setting (Holm and Thinggaard, 2011; Lesage et al., 2012). On the other hand, some empirical evidence suggests that joint audit leads to higher actual and perceived audit quality in voluntary joint audit settings (Zerni et al., 2012). Second, there is some empirical evidence that joint audit leads to additional costs, with some papers concluding that audit costs are higher in joint audits (Holm and Thinggaard, 2011; André et al., 2012; Lesage et al., 2012). In voluntary settings, the results are mixed: both higher audit fees for joint audits (Zerni et al., 2012) and lower audit fees for joint audits (Ittonen and Peni, 2012) can be observed. Third, there is some empirical evidence that the concentration of the audit market is lower in joint 
audit settings (France and Denmark) than in other countries (Ballas and Fafaliou, 2008). Fourth, the joint audit should be seen as a mechanism that is embedded in a broader institutional context and should not be considered in isolation from other factors that might impact the audit market. At least for some research questions, the mixed evidence reported by this literature review indicates that various country-level characteristics are simultaneously at play. This lack of clear evidence echoes the concerns raised by the Federation of European Accountants (FEE) "that audit consortia could have an impact on helping to change the concentration in the audit market, although its impact on audit quality is unclear" (FEE, 2011, p. 11). The EC supports the implicit, and unproven, assumption that enhanced audit market structure - potentially an outcome of a joint audit setting — will lead to better audit quality (Humphrey et al., 2011). Finally, this paper shows that many consequences of the joint audit regulation are still not known in detail, partly for methodological reasons but also due to limited data access.

The literature review strongly suggests that arguments raised by proponents and opponents of the joint audit should not be evaluated only on joint audit efficiency. This is because, for one, the impact of joint audit is difficult to isolate, and furthermore because the issue is broader than a simple question of audit costs or audit quality. The initial concerns raised by regulators and policy-makers about the potential risks in case of a failure involving one of the remaining Big 4 audit firms should be addressed by researchers and policy-makers with a more direct focus on the impact of joint audit on audit market concentration and on the measurement of the effect of market concentration on audit quality. 


\section{References}

Aktiebolagslag (2005) Aktiebolagslag 2005:551, Sweden, (Swedish Companies Act).

AMF (2011) Etude relative aux honoraires versés aux commissaires aux comptes et à leur réseau au titre de la période 2010 par les groupes du CAC 40, de l'eurostoxx 50 et d'un échantillon de 42 sociétés des compartiments b et c d'eurolist [Survey of fees paid to statutory auditors and their networks for 2010 by CAC 40 and Eurostoxx 50 companies and by a sample of 42 companies in the $B$ and $C$ compartments of Eurolist], Autorité des Marchés Financiers, Paris.

André, P., Broye, G., Pong, C. K. M. and Schatt, A. (2012) Are joint audits associated with higher audit fees?, Working paper, Available at SSRN: http://ssrn.com/abstract=203900, accessed $31 / 01 / 2013$.

Audousset-Coulier, S. (2008) La publication des honoraires d'audit par les sociétés cotées françaises, déterminants de la publication volontaire et du niveau des honoraires [Determinants of the voluntary disclosure audit fees and audit pricing in a joint audit setting]. PhD dissertation, HEC Paris.

Audousset-Coulier, S. (2012) "Two big" or not "two big"? The consequences of appointing two Big 4 auditors on audit pricing in a joint audit setting. Available at:

http://ssrn.com/abstract=2083871 or http://dx.doi.org/10.2139/ssrn.2083871, accessed 12/11/2012.

Ballas, A. A. and Fafaliou, I. (2008) Market shares and concentration in the EU auditing industry: The effect of andersen's demise, International Advances in Economic Research, 14, pp. 485-497.

Banks Amendment Act (2003) Banks Amendment Act, South Africa, Act no. 19 of 2003, sec. 42. http://www.info.gov.za/view/DownloadFileAction?id=67994, accessed 12/11/2012.

Beattie, V., Goodacre, A. and Fearnley, S. (2003) And then there were four:A study of UK audit market concentration--causes, consequences and the scope for market adjustment, Journal of Financial Regulation \& Compliance, 11(3), pp. 250.

Becker, C. L., Defond, M. L., Jiambalvo, J. and Subramanyam, K. R. (1998) The effect of audit quality on earnings management., Contemporary Accounting Research, 15(1), pp. 1-24.

Bédard, J., Piot, C. and Schatt, A. (2012) Was the European Commission Green Paper right? An evaluation of the French experience with joint auditing. http://ssrn.com/abstract=2165595 or http://dx.doi.org/10.2139/ssrn.2165595, accessed 12/11/2012.

Bennecib, J. (2004) De l'efficacité du co-commissariat aux comptes [On the efficiency of joint audit]. PhD dissertation, Paris Dauphine University.

Bennouri, M., Nekhili, M. and Touron, P. (2012) Does auditors' reputation discourage related party transactions? The French case. (March 20, 2012). 2012 Financial Markets \& Corporate Governance Conference. http://ssrn.com/abstract $=1823464$ or http://dx.doi.org/10.2139/ssrn.1823464, accessed 12/11/2012.

Boone, J. P., Khurana, I. K. and Raman, K. K. (2012) Audit market concentration and auditor tolerance for earnings management, Contemporary Accounting Research, 29(4), pp. 1171-1203

Broye, G. (2007) Concentration du marché de l'audit: Un état des lieux [Audit market concentration in France: A state of the art], Revue Française de Comptabilité, 399, pp. 34-37.

Carcello, J. V., Hermanson, R. H. and McGrath, N. T. (1992) Audit quality attributes: The perceptions of audit partners, preparers, and financial statement users., Auditing, 11(1), pp. 1-15.

Companies Act (2008) Companies Act (Act $n^{\circ} 71$ of 2008), South Africa. http://www.saica.co.za/Portals/0/Technical/LegalAndGovernance/Act 712008 Companies Act.pdf, accessed 12/11/2012.

Craswell, A. T. (1999) Does the provision of non-audit services impair auditor independence?, International Journal of Auditing, 3(1), pp. 29-40.

Danish Financial Statement Act (2001) Forslag til lov om erhvervsdrivende virksomheders aflæggelse af årsregnskab m.V. (årsregnskabsloven), §135 [The proposal to the Danish Financial Statements Act, §135]. 
DeAngelo, L. E. (1981) Auditor size and audit quality, Journal of Accounting and Economics, 3(3), pp. 183-199.

DeFond, M. L. and Francis, J. R. (2005) Audit research after Sarbanes-Oxley., Auditing, 24, pp. 5-30.

DeFond, M. L. and Park, C. (2001) The reversal of abnormal accruals and the market valuation of earnings surprises, The Accounting Review, 76(3), pp. 375-404.

DeFond, M. L., Raghunandan, K. and Subramanyam, K. R. (2002) Do non-audit service fees impair auditor independence? Evidence from going concern audit opinions, Journal of Accounting Research, 40(4), pp. 1247-1274.

Deng, M., Lu, T., Simunic, D. A. and Ye, M. (2012) Do joint audits improve or impair audit quality?, (December 29, 2012). Rotman School of Management Working Paper No. 2111710; CAAA Annual Conference 2013. Available at SSRN: http://ssrn.com/abstract=2111710 or http://dx.doi.org/10.2139/ssrn.2111710.

EC (2001) A study on systems of civil liability of statutory auditors in the context of a single market for auditing services in the European union, European Commission, http://ec.europa.eu/internal_market/auditing/docs/liability/auditliability_en.pdf, accessed 12/11/2012, Brussels.

EC (2010) Green Paper: Audit policy: Lessons from the crisis, 13th of October 2010, European Commission, Brussels, pp. 1-21.

EC (2011a) Restoring confidence in financial statements: The European commission aims at a higher quality, dynamic and open audit market, 30 November 2011, European Commission, Brussels.

EC (2011b) Summary of responses Green Paper - audit policy: Lessons from the crisis, 4th February 2011, European Commission, Brussels, pp. 1-36.

FEE (2011) Federation of European Accountants: Briefing paper: Standing for trust and integrity. http://www.fee.be/fileupload/upload/Briefing Paper 04 Appointment of the Auditor 11063062011582130. pdf, accessed 12/11/2012.

Försäkringsrörelselag (2010) Försäkringsrörelselag, \#2043, Sweden (The Swedish Insurance Business Act).

Francis, J., LaFond, R. Z., Olsson, P. and Schipper, K. (2005) The market pricing of accruals quality, Journal of Accounting and Economics, 29, pp. 295-327.

Francis, J. R. (2004) What do we know about audit quality?, The British Accounting Review, 36(4), pp. 345-368.

Francis, J. R. (2011) A framework for understanding and researching audit quality, Auditing: A Journal of Practice and Theory, 30(2), pp. 125-132.

Francis, J. R., Michas, P. N. and Seavey, S. E. (2012) Does audit market concentration harm the quality of audited earnings? Evidence from audit markets in 42 countries, Contemporary Accounting Research, forthcoming.

Francis, J. R., Vanstraelen, A. and Richard, C. (2009) Assessing France's joint audit requirement: Are two heads better than one ?, Auditing, 28(2), pp. 35-63.

Francis, J. R. and Wang, D. (2008) The joint effect of investor protection and Big 4 audits on earnings quality around the world, Contemporary Accounting Research, 25(1), pp. 157-191.

Gonthier-Besacier, N. and Schatt, A. (2007) Determinants of audit fees for French quoted firms, Managerial Auditing Journal, 22(2), pp. 139-160.

Heckman, J. J. (1979) Sample selection bias as a specification error, Econometrica, 47, pp. 153-161.

HoL (2011) Auditors: Market concentration and their role, March, HL Paper 119-I, House Of Lords Select Committee on Economic Affairs, The Stationery Office Limited, London.

Holm, C. and Thinggaard, F. (2011) Joint audits - benefit or burden?, http://papers.ssrn.com/sol3/papers.cfm?abstract_id=1702867, accessed 31/08/2012.

Holm, C. and Thinggaard, F. (2012) Balancing auditor choices during the transition from a mandatory to a voluntary joint audit system in Denmark.

http://aaahq.org/AM2012/display.cfm?Filename=SubID_1740.pdf\&MIMEType=appli cation\%2Fpdf, accessed 15/08/2012. 
Holm, C. and Warming-Rasmussen, B. (2008) An account of accountants. Audit regulation and the audit profession in Denmark, in Quick, R., et al., Eds, Auditing, trust and governance regulation in Europe, Routledge, London.

Huber, N. (2011) The concentration battle, International Accounting Bulletin, pp. 6-11.

Humphrey, C., Kausar, A., Loft, A. and Woods, M. (2011) Regulating audit beyond the crisis: A critical discussion of the EU Green Paper, European Accounting Review, 20(3), pp. 431-457.

Ittonen, K. and Peni, E. (2012) Auditor's gender and audit fees, The International Journal of Auditing, 16(1), pp. 1-18.

Jones, J. (1991) Earnings management during import relief investigations, Journal of Accounting Research, 29(2), pp. 193-228.

Karjalainen, J. (2011) Audit quality and cost of debt capital for private firms: Evidence from Finland, International Journal of Auditing, 15(1), pp. 88-108.

Kida, T. (1980) An investigation into auditors' continuity and related qualification judgments, Journal of Accounting Research, 18(2), pp. 506-523.

Lag om bank- och finansieringsrörelse (2004) Lag om bank- och finansieringsrörelse, \#297, Sweden, (The Swedish Banking and Financing Business Act).

Le Maux, J. (2004) Le co-commissariat aux comptes à la française [The French model of joint audit], Revue Française de Comptabilité, 266, pp. 34-38.

Lesage, C. and Ratzinger-Sakel, N. (2012) Are the findings of international studies reliable? The joint audit example. Working paper.

Lesage, C., Ratzinger-Sakel, N. and Kettunen, J. (2012) Struggle over joint audit: On behalf of public interest?, http://papers.ssrn.com/abstract=2176729, accessed 12/11/2012.

Lobo, G. L., Paugam, L. and Casta, J.-F. (2013) Impact of joint auditor pair on timely loss recognition: Evidence from impairment tests.

http://papers.ssrn.com/sol3/papers.cfm?abstract_id=1985541, accessed 12/11/2012.

Maggina, A. (2012) Joint audit in Greece: Evidence from Greek listed companies. http://aaahq.org/AM2012/display.cfm?Filename=SubID_292.pdf\&MIMEType=applic ation\%2Fpdf, accessed 12/11/2012.

Marmousez, S. (2008) Le choix de la composition du collège des commissaires aux comptes : Déterminants et conséquences [Determinants and consequences of the auditor pair choice in a joint audit setting]. PhD dissertation, HEC Paris.

Marmousez, S. (2012) Examining a French exception: The determinants of the choice of joint-auditors (in French), Comptabilité - Contrôle - Audit, 18(1), pp. 121-152.

Mutchler, J. F. (1984) Auditors' perceptions of the going-concern opinion decision, Auditing: A Journal of Practice and Theory, 3(2), pp. 17-30.

NEP-100 (2011) Arrêté du 10 avril 2007 published in J.O. n 103 from 3 Mai 2007, modified 3 August 2011.

Niemi, L. (2002) Do firms pay for audit risk ? Evidence on risk premiums in audit fees after direct control for audit effort, International Journal of Auditing, 6(1), pp. 37-51.

Palmrose, Z.-V. (1986) Audit fees and auditor size: Further evidence., Journal of Accounting Research, 24(1), pp. 97-110.

Piot, C. (2003) Coûts d'agence et changements de commissaire aux comptes: Une approche empirique [Agency costs and auditor change: An empirical approach], Comptabilité Contrôle Audit, 9(2), pp. 5-30.

Piot, C. (2007) Auditor concentration in a joint-audit environment: The French market 1997-2003, Managerial Auditing Journal, 22(2), pp. 161-176.

Piot, C. (2008) Concentration et compétitivité du marché de l'audit en France : Une étude longitudinale 1997-2003 [Concentration and competition of the French audit market: A longitudinal study 1997-2003], Finance Contrôle stratégie, 11(4), pp. 31-64.

Quick, R. (2012) EC Green Paper proposals and audit quality, Accounting in Europe, 9(1), pp. 17-38.

Richardson, A. J. (2001) The Canadian audit market in the first half of the twentieth century, Accounting Historians Journal, 28(2), pp. 109-139. 
Robinson, D. (2008) Auditor independence and auditor-provided tax service: Evidence from goingconcern audit opinions prior to bankruptcy filings, Auditing: A Journal of Practice \& Theory, 27(2), pp. 31-54.

Schelleman, C. and Knechel, W. R. (2010) Short-term accruals and the pricing and production of audit services, Auditing: A Journal of Practice and Theory 29, pp. 221-250.

Shammari, B. A., Yaqout, A. A. and Hussaini, A. A. (2008) Determinants of audit fees in kuwait, Journal of Academy of Business and Economics, 8(1), pp. 140-152.

Simunic, D. A. (1980) The pricing of audit services: Theory and evidence, Journal of Accounting Research, 18(1), pp. 161-190.

Thinggaard, F. and Kiertzner, L. (2008) Determinants of audit fees: Evidence from a small capital market with a joint audit requirement, International Journal of Auditing, 12(2), pp. 141-158.

Wolk, C. M., Michelson, S. E. and Wooton, C. W. (2001) Auditor concentration and market shares in the US: 1988-1999 a descriptive note, The British Accounting Review, 33(2), pp. 157-174.

Zerni, M., Haapamäki, E., Järvinen, T. and Niemi, L. (2012) Do joint audits improve audit quality? Evidence from voluntary joint audits, European Accounting Review, 21(4), pp. 731-765.

Zerni, M., Kallunki, J.-P. and Nilsson, H. (2010) The entrenchment problem, corporate governance mechanisms, and firm value, Contemporary Accounting Research, 27(4), pp. 1169-1206. 
Table 1: Main empirical studies - Impact of joint audit

Panel A: Audit quality and audit cost

\begin{tabular}{|c|c|c|c|c|c|}
\hline Authors & Sample & $\begin{array}{l}\text { Mandatory/ } \\
\text { Voluntary }\end{array}$ & Research Question & Main findings related to joint audit & $\begin{array}{c}\text { Publication } \\
\text { outlet }\end{array}$ \\
\hline $\begin{array}{l}\text { André et al. } \\
\text { (2012) }\end{array}$ & $\begin{array}{c}\text { Listed companies years } 2007-2009 ; 177 \\
\text { French, } 102 \text { Italian, and } 210 \mathrm{UK} \\
\text { companies }\end{array}$ & Mandatory & $\begin{array}{c}\text { Audit cost } \\
\text { Do mandatory joint audits lead to } \\
\text { higher audit fees than those for } \\
\text { single audits? }\end{array}$ & $\begin{array}{c}\text { Mandatory joint audits lead to higher } \\
\text { audit fees. }\end{array}$ & $\begin{array}{l}\text { Working } \\
\text { paper }\end{array}$ \\
\hline $\begin{array}{l}\text { Holm and } \\
\text { Thinggaard } \\
\text { (2011) }\end{array}$ & $\begin{array}{l}117 \text { listed non-financial Danish } \\
\text { companies, years 2003-2007 }\end{array}$ & $\begin{array}{l}\text { Mandatory / } \\
\text { Voluntary }\end{array}$ & $\begin{array}{l}\text { Audit quality and audit cost } \\
\text { Does the switch from joint to } \\
\text { single audit impact the audit costs } \\
\text { or audit quality? }\end{array}$ & $\begin{array}{l}\text { Joint audits are not better able to constrain } \\
\text { earnings management than single audits. } \\
\text { Companies that switch from joint audit to } \\
\text { single audit receive a reduction in audit } \\
\text { fees on the first year after the switch. }\end{array}$ & $\begin{array}{l}\text { Working } \\
\text { paper }\end{array}$ \\
\hline $\begin{array}{l}\text { Ittonen and } \\
\text { Peni } \\
\text { (TIJAUD } \\
\text { 2012) }\end{array}$ & $\begin{array}{l}715 \text { non-financial companies listed in } \\
\text { Denmark, Finland and Sweden, year } 2007\end{array}$ & Voluntary & $\begin{array}{c}\text { Audit cost } \\
\text { Main research question: Does } \\
\text { auditor's gender affect audit fees? } \\
\text { As a side research question, the } \\
\text { effect of voluntary joint audit on } \\
\text { audit fees is also addressed. }\end{array}$ & $\begin{array}{c}\text { Voluntary joint audit is associated with } \\
\text { lower audit fees than fees for single } \\
\text { audits. }\end{array}$ & $\begin{array}{l}\text { Published } \\
\text { paper }\end{array}$ \\
\hline $\begin{array}{l}\text { Lesage et al. } \\
\qquad(2012)\end{array}$ & $\begin{array}{l}432 \text { (582) listed Danish companies, years } \\
\text { 2005-2010 (2002-2010) }\end{array}$ & $\begin{array}{l}\text { Mandatory / } \\
\text { Voluntary }\end{array}$ & $\begin{array}{l}\text { Audit quality and audit cost } \\
\text { Does the switch from } \\
\text { mandatory/voluntary joint audit to } \\
\text { single audit have influence on audit } \\
\text { fees or financial statement quality? }\end{array}$ & $\begin{array}{l}\text { Joint audit is neither associated with } \\
\text { higher audit fees nor with higher audit } \\
\text { quality. }\end{array}$ & $\begin{array}{l}\text { Working } \\
\text { paper }\end{array}$ \\
\hline $\begin{array}{l}\text { Lesage and } \\
\text { Ratzinger- } \\
\text { Sakel } \\
(2012)\end{array}$ & $\begin{array}{l}386 \text { French and } 386 \text { German listed non- } \\
\text { financial companies (matched sample), } \\
\text { years 2005-2010 }\end{array}$ & Mandatory & $\begin{array}{l}\text { Audit quality and audit cost } \\
\text { Are mandatory joint audits } \\
\text { associated with higher fees (audit } \\
\text { and total fees)? Are mandatory } \\
\text { joint audits associated with higher } \\
\text { audit quality? }\end{array}$ & $\begin{array}{l}\text { Mandatory joint audits are not associated } \\
\text { with higher audit quality. } \\
\text { Mandatory joint audit appears to be } \\
\text { associated with higher audit and higher } \\
\text { total fees, although the result should be } \\
\text { interpreted with caution. }\end{array}$ & $\begin{array}{l}\text { Working } \\
\text { paper }\end{array}$ \\
\hline $\begin{array}{l}\text { Zerni et al. } \\
\text { (EAR 2012) }\end{array}$ & $\begin{array}{l}\text { Different samples of Swedish companies: } \\
\text { a) a sample of listed companies: } 1257 \\
\text { firm-year observations and b) samples of } \\
\text { privately held companies (between } 848 \\
\text { and } 1160 \text { observations depending on the } \\
\text { test), years } 2001-2007\end{array}$ & Voluntary & $\begin{array}{c}\text { Audit quality and audit cost } \\
\text { Do voluntary joint audits improve } \\
\text { audit quality? } \\
\text { Does voluntary joint audit increase } \\
\text { audit fees? }\end{array}$ & $\begin{array}{l}\text { Voluntary joint audits improve perceived } \\
\text { and actual audit quality. } \\
\text { Voluntary joint audits lead to higher audit } \\
\text { fees. }\end{array}$ & $\begin{array}{l}\text { Published } \\
\text { paper }\end{array}$ \\
\hline
\end{tabular}




\begin{tabular}{|l|l|l|l|l|}
\hline Authors & Sample & $\begin{array}{l}\text { Mandatory/ } \\
\text { Voluntary }\end{array}$ & Research question & Main findings related to joint audit \\
\hline $\begin{array}{l}\text { Zerni et al. } \\
\text { (CAR 2010) }\end{array}$ & $\begin{array}{l}\text { Sweden, 1171 listed non-financial } \\
\text { companies, years 2000-2006 }\end{array}$ & Voluntary & $\begin{array}{l}\text { Audit quality } \\
\text { Can corporate governance } \\
\text { devices including joint audit } \\
\text { effectively mitigate the } \\
\text { entrenchment problem and the } \\
\text { associated entrenchment } \\
\text { discount? }\end{array}$ & $\begin{array}{l}\text { Joint audit mitigates entrenchement } \\
\text { discounts. } \\
\text { Thingle audit choice aspect which is } \\
\text { siscussed in table 2 }\end{array}$ \\
\hline
\end{tabular}

\section{Panel B: Market concentration}

\begin{tabular}{|c|c|c|c|c|c|}
\hline $\begin{array}{l}\text { Ballas and } \\
\text { Fafaliou } \\
\text { (IAER 2008) }\end{array}$ & $\begin{array}{l}\text { Sample of 2,862 firms from } 15 \text { European } \\
\text { countries, years 1998-2001 and 2002-- } \\
2004\end{array}$ & Mandatory & $\begin{array}{l}\text { Audit market concentration } \\
\text { How has the concentration of the } \\
\text { audit market in Europe evolved } \\
\text { after the demise of Arthur } \\
\text { Andersen? }\end{array}$ & $\begin{array}{l}\text { The audit market concentration has } \\
\text { increased overall during the period. } \\
\text { However, the concentration has decreased } \\
\text { in France and Denmark after the dissolution } \\
\text { of Arthur Andersen. }\end{array}$ & $\begin{array}{l}\text { Published } \\
\text { paper }\end{array}$ \\
\hline $\begin{array}{l}\text { Broye } \\
\text { (RFC 2007) }\end{array}$ & 428 French listed firms in 2005 & Mandatory & $\begin{array}{l}\text { Audit market concentration } \\
\text { What is the level of concentraton } \\
\text { of the French audit market after } \\
\text { the merger of two major local } \\
\text { audit firms (Salustro and BDO) } \\
\text { with Big } 4 \text { audit firms? }\end{array}$ & $\begin{array}{l}\text { Big } 4 \text { firms are in charge of about half of } \\
\text { the } 852 \text { possible audit mandates but earn } \\
86 \% \text { of the audit fees. The concentration is } \\
\text { higher in the large client segment and lower } \\
\text { in the medium-and-small client segment. } \\
\text { By comparison, UK Big } 4 \text { firms earn } 99 \% \\
\text { of the audit fees on the } 350 \text { largest clients. }\end{array}$ & $\begin{array}{l}\text { Published } \\
\text { paper } \\
\text { (in French) }\end{array}$ \\
\hline $\begin{array}{l}\text { Piot } \\
\text { (MAJ 2007) }\end{array}$ & $\begin{array}{l}817 \text { listed French companies in the year } \\
\text { 1997, and } 887 \text { listed French companies in } \\
\text { the year } 2003\end{array}$ & Mandatory & $\begin{array}{l}\text { Audit market concentration } \\
\text { How has the audit market } \\
\text { concentration evolved in a } \\
\text { mandatory joint-audit } \\
\text { environment between } 1997 \text { and } \\
2003 \text { ? }\end{array}$ & $\begin{array}{l}\text { The French audit market is less } \\
\text { concentrated than audit markets elsewhere } \\
\text { in Europe, although audit market } \\
\text { concentration did increase during this time } \\
\text { frame in France. }\end{array}$ & $\begin{array}{c}\text { Published } \\
\text { paper }\end{array}$ \\
\hline $\begin{array}{l}\text { Piot } \\
\text { (FCS 2008) }\end{array}$ & $\begin{array}{l}\text { French listed firms observed in year } 1997 \\
\text { and year } 2003\end{array}$ & Mandatory & $\begin{array}{l}\text { Audit market concentration } \\
\text { Is the French audit market still } \\
\text { competitive after the Big } 6 \text { to Big } \\
4 \text { mergers? }\end{array}$ & $\begin{array}{l}\text { The concentration has increased over the } \\
\text { period and concentration ratios characterise } \\
\text { a closed oligopoly. However, Herfindahl } \\
\text { indices suggest that the market is still price } \\
\text { competitive in } 2003 \text {. }\end{array}$ & $\begin{array}{l}\text { Published } \\
\text { paper } \\
\text { (in French) }\end{array}$ \\
\hline
\end{tabular}


Table 2: Main empirical studies - Other studies on joint audit

\begin{tabular}{|c|c|c|c|c|c|}
\hline Authors & Sample & $\begin{array}{l}\text { Mandatory/ } \\
\text { Voluntary }\end{array}$ & Research Question & Main Findings related to joint audit & $\begin{array}{c}\text { Publication } \\
\text { outlet }\end{array}$ \\
\hline $\begin{array}{l}\text { Audousset- } \\
\text { Coulier } \\
\text { (2012) }\end{array}$ & $\begin{array}{l}254 \text { listed French companies, } \\
\text { years } 2002 \text { and } 2003\end{array}$ & Mandatory & $\begin{array}{l}\text { Effect of auditor choice on audit } \\
\text { cost } \\
\text { What is the consequence of } \\
\text { appointing two Big } 4 \text { auditors on } \\
\text { audit pricing? }\end{array}$ & $\begin{array}{l}\text { The choices of one Big } 4 \text { paired whith a } \\
\text { non-Big and of the choice of two Big } 4 \text { both } \\
\text { lead to the payment of Big } 4 \text { premiums of } \\
\text { comparable magnitudes. }\end{array}$ & $\begin{array}{l}\text { Working } \\
\text { paper }\end{array}$ \\
\hline $\begin{array}{l}\text { Bennouri, } \\
\text { Nekhili and } \\
\text { Touron } \\
\text { (2012) }\end{array}$ & $\begin{array}{l}85 \text { listed French companies, } \\
\text { years 2002-2008 }\end{array}$ & Mandatory & $\begin{array}{l}\text { Effect of auditor choice on audit } \\
\text { quality } \\
\text { Does auditors' reputation } \\
\text { discourage related party } \\
\text { transactions? }\end{array}$ & $\begin{array}{l}\text { Companies with two Big } 4 \text { auditors have a } \\
\text { lower number of related party transactions. }\end{array}$ & $\begin{array}{l}\text { Working } \\
\text { paper }\end{array}$ \\
\hline $\begin{array}{l}\text { Francis et al. } \\
\text { (AJPT 2009) }\end{array}$ & $\begin{array}{c}467 \text { listed French companies, } \\
\text { year } 2003\end{array}$ & Mandatory & $\begin{array}{l}\text { Determinants of joint auditor pair } \\
\text { choice and effect of auditor } \\
\text { choice on audit quality } \\
\text { What are the determinants of } \\
\text { joint auditor pair choice in the } \\
\text { context of mandatory joint audit? } \\
\text { Does having two Big 4 audit } \\
\text { firms improve the auditees' } \\
\text { financial statement quality as } \\
\text { compared to other auditor pairs? }\end{array}$ & $\begin{array}{l}\text { Companies with less concentrated } \\
\text { ownership structures and lower rates of } \\
\text { family ownership are more likely to appoint } \\
\text { at least one Big } 4 \text { audit firm. } \\
\text { Companies audited by two Big } 4 \text { audit } \\
\text { firms have smaller abnormal income- } \\
\text { increasing accruals. }\end{array}$ & $\begin{array}{l}\text { Published } \\
\text { paper }\end{array}$ \\
\hline $\begin{array}{l}\text { Gonthier- } \\
\text { Besacier and } \\
\text { Schatt } \\
\text { (MAJ 2007) }\end{array}$ & $\begin{array}{l}127 \text { listed non-financial French } \\
\text { companies, year } 2002\end{array}$ & Mandatory & $\begin{array}{l}\text { Effect of auditor choice and fee } \\
\text { balance on audit cost } \\
\text { What are the determinants of } \\
\text { scaled audit fees ( i.e., audit } \\
\text { fees/client firm size) for French } \\
\text { listed companies? The fee } \\
\text { balance effect is also discussed. }\end{array}$ & $\begin{array}{l}\text { The audit fee / client size ratio is lower for } \\
\text { client companies audited by two Big } 4 \\
\text { firms. } \\
\text { The balanced allocation of audit fees } \\
\text { between the joint auditors does not affect } \\
\text { audit fees. }\end{array}$ & $\begin{array}{l}\text { Published } \\
\text { paper }\end{array}$ \\
\hline
\end{tabular}




\begin{tabular}{|c|c|c|c|c|c|}
\hline $\begin{array}{l}\text { Holm and } \\
\text { Thinggaard } \\
\text { (2012) }\end{array}$ & $\begin{array}{l}116 \text { listed non-financial Danish } \\
\text { companies, years after } 2005\end{array}$ & Voluntary & $\begin{array}{l}\text { Determinants of auditor pair } \\
\text { choice } \\
\text { What are the determinants of } \\
\text { auditor choice in the context of } \\
\text { the transition from a mandatory } \\
\text { to a voluntary joint audit setting? }\end{array}$ & $\begin{array}{l}\text { Voluntary joint audits are associated with } \\
\text { lower non-audit service fees and seem to } \\
\text { mitigate threats to auditors independence. }\end{array}$ & $\begin{array}{c}\text { Working } \\
\text { paper }\end{array}$ \\
\hline Authors & Sample & $\begin{array}{l}\text { Mandatory/ } \\
\text { Voluntary }\end{array}$ & Research Question & Main Findings related to joint audit & $\begin{array}{c}\text { Publication } \\
\text { outlet }\end{array}$ \\
\hline $\begin{array}{l}\text { Marmousez } \\
(\text { CCA 2012) }\end{array}$ & 175 French listed companies, year 2003 & Mandatory & $\begin{array}{l}\text { Determinants of auditor pair } \\
\text { choice } \\
\text { What are the determinants of } \\
\text { auditor pair choice in the French } \\
\text { context? }\end{array}$ & $\begin{array}{l}\text { Small clients have no incentive to hire two } \\
\text { Big } 4 \text { auditors. } \\
\text { Clients with audit committees are more } \\
\text { likely to hire two Big } 4 \text { auditors. } \\
\text { Larger and international clients tend to hire } \\
\text { two Big } 4 \text { auditors. }\end{array}$ & $\begin{array}{l}\text { Published } \\
\text { paper } \\
\text { (in French) }\end{array}$ \\
\hline $\begin{array}{l}\text { Shammari et } \\
\text { al. } \\
\text { (JABE 2008) }\end{array}$ & $\begin{array}{l}91 \text { firms listed on the Kuwait stock } \\
\text { exchange, year } 2006\end{array}$ & Mandatory & $\begin{array}{l}\text { Effect of auditor choice on audit } \\
\text { cost } \\
\text { What are the determinants of } \\
\text { audit fees in Kuwait? }\end{array}$ & $\begin{array}{l}\text { The choice of one Big } 4 \text { or two Big } 4 \\
\text { among joint auditors does not lead to the } \\
\text { payment of a Big } 4 \text { premium. }\end{array}$ & $\begin{array}{l}\text { Published } \\
\text { paper }\end{array}$ \\
\hline $\begin{array}{l}\text { Thinggaard } \\
\text { and Kiertzner } \\
\text { (TIJAUD } \\
\text { 2008) }\end{array}$ & $\begin{array}{l}126 \text { non-financial listed Danish } \\
\text { companies, year } 2002\end{array}$ & Mandatory & $\begin{array}{l}\text { Effect of auditor choice and fee } \\
\text { balance on audit cost } \\
\text { What are the determinants of } \\
\text { audit fees and does the fee } \\
\text { allocation between joint auditors } \\
\text { have an effect on the audit fees? }\end{array}$ & $\begin{array}{l}\text { "De facto" joint audits (i.e., a balanced } \\
\text { allocation of the audit fees between joint } \\
\text { auditors) decrease audit fees in Denmark. }\end{array}$ & $\begin{array}{l}\text { Published } \\
\text { paper }\end{array}$ \\
\hline $\begin{array}{l}\text { Zerni et al. } \\
\text { (CAR 2010) }\end{array}$ & $\begin{array}{l}\text { Sweden, } 1171 \text { listed non-financial } \\
\text { companies, years 2000-2006 }\end{array}$ & Voluntary & $\begin{array}{l}\text { Reasons for opting for joint } \\
\text { audits in a voluntary setting. } \\
\text { (This is a side research question } \\
\text { in the paper. The main research } \\
\text { question deals with audit quality } \\
\text { and is summarised in Table 1, } \\
\text { Panel A) }\end{array}$ & $\begin{array}{l}\text { Board members' equity ownership and a } \\
\text { strong minority ownership increase the } \\
\text { likelihood that a firm employs joint } \\
\text { auditors. } \\
\text { The audit quality aspect is discussed in } \\
\text { Table 1, Panel A }\end{array}$ & $\begin{array}{l}\text { Published } \\
\text { paper }\end{array}$ \\
\hline
\end{tabular}


